\title{
Anticancer and Antifolate Activities of Extracts of Six Saudi Arabian Wild Plants Used in Folk Medicine
}

\author{
Marzough Aziz Dager Albalawi, Nour Ahmed Osman Bashir and Amany Tawfik \\ Department of Chemistry, University College at Alwajh, University of Tabuk, Tabuk 71491, Saudi Arabia
}

Received: May 21, 2015 / Accepted: July 26, 2015 / Published: July 30, 2015.

\begin{abstract}
Six indigenous folk medicinal plants growing wild in the area of Tabuk, Saudi Arabia which were selected for the study of their phytochemistry as well as their biological activities as antitumor and antifolate agents. Antitumor activities of methanol extracts of the six plants were measured in vitro using three human tumor cell lines (breast, lung and CNS cancers) while antifolate activities were assessed using commercial dihyrofolate reductase obtained from Sigma Co. Among the six plant extracts tested, the most remarkable were those of Caralluma sinaica and Fagonia tenuifolia. Caralluma extract showed strong antitumor activity (low $\mathrm{GI}_{50}$ ) against the three human tumor cell lines. Fagonia extract, on the other hand, was quite inhibitory to the growth of CNS cancer and breast cancer cell lines but much less so against lung cancer cells. Extracts of both Sonchus oleraceus and Caralluma sinaica were strongly inhibitory to DHFR. These results suggest that the mechanism of anticancer activity of Caralluma plant is through DHFR inhibition but that of Fagonia may follow a different path.
\end{abstract}

Key words: Saudi Arabia plants, Caralluma, Fagonia, Sonchus, anticancer, antitumor, antifolate, antimalarial.

\section{Introduction}

Higher plants constitute a major valuable source of natural products useful as drugs on their own right or as lead compounds for commercial drug production by total or partial synthesis. The role of natural products is expected to widen as the current explosion of genetic information and genome mining may even lead to the biosynthesis of unknown molecular structures [1], developments greatly aided by the continual improvement of laboratory separation and chemical identification techniques [2].

Natural products, of course, also find applications in several industries other than the pharmaceutical industry, areas such as functional foods and food additives [2] as well as seemingly remote areas like the textile industry [3].

Many plants growing wild among the Saudi flora are traditionally used in local medicine for nutraceutical

Corresponding author: Nour Ahmed Osman Bashir, Ph.D., associate professor, research field: organic chemistry (natural products chemistry). E-mail: nanseeosman2011@gmail.com. purposes or for the treatment of several ailments. However, most of these folk medicinal plants still await scientific investigation of their claimed health benefits.

The authors have selected six wild Saudi plants, locally reputed to be of remedial value, in order to investigate the biological activities of their extracts using two bioassay protocols, namely, in vitro antitumor (anti-cancer) potential and the ability to inhibit the enzyme DHFR (dihydrofolate reductase) (antifolate activity). In biological systems, DHFR enzyme catalyzes the formation of tetrahydrofolate by reduction of dihydrofolate using NADPH as a cofactor. Tetrahydrofolate and its one carbon adducts are required for de novo synthesis of purines and thymidylate, as well as some amino acids. DHFR inhibition causes disruption of purine and thymidylate biosynthesis and DNA replication, leading to cell death [4]. Therefore, DHFR has been an attractive target for chemotherapy of many diseases including cancer [5], malaria [6], leishmania and trypanosomiasis [7] and 
bacterial infections [8].

The six plants selected for the present study are listed in Table 1. Following are brief data on interesting biological activities and/or folk medicinal uses that influenced the selection of each of these plants for the study. A member of the plant genus Arnebia, A. hispidissima, of the family Boraginaceae is used for the treatment of tongue and throat ailments in Indian traditional medicine. The crude hexane extract of Indian A. hispidissimawas shown to possess marked antimicrobial activity against bacteria and a lesser effect against fungi [9]. Caralluma, a xerophytic plant genus belonging to the subfamily of Asclepiadoideae in the family Apocynaceae, is distributed in dry regions of tropical Asia and Africa, the majority of species being indigenous to the Indian subcontinent and the Arabian Peninsula [10]. Species of the genus, such as $C$. adscendens, were reported to possess appetite-suppressant activity and weight loss properties; the bioactive compounds responsible suggested to be 14ß-hydroxypregnane derivatives [10]. Aspects of ethnobotany, phytochemistry and pharmacology of the genus have recently been reviewed [11]. Ethnomedical uses of Caralluma were recorded by these authors from several Asian countries for the treatment of diseases including diabetes, leprosy, obesity and rheumatism [11]. Lavandula pubecens is an aromatic folk medicinal plant of repute in Saudi Arabia and Yemen $[12,13]$. Sonchus oleraceus is known worldwide for its folk medicinal properties including uses as antimalarial, for headaches and general pain-relief [14]. In fact a number of biological activities have been proven for the plant including anti-inflammatory and antipyretic effects in rats [14], antimalaial potential [15], antioxidant activity [16] and anxiolytic-like effects on mice [17]. Aqueous and alcoholic root extracts of Verbesina encelioides, a folk medicinal plant used to treat diabetes, were reported to lower blood sugar levels in mice [18]. Another interesting biological activity of the plant was its experimentally demonstrated toxicity to sheep [19].

\section{Materials and Methods:}

2.1 General: All solvents and chemicals used were of standard analytical grade

\subsection{Collection and authentification of the plants}

Aerial parts of the six plants of the study (namely, Arnebiadecumbents, Caralumasinica, Fagonia tenuifolia, Lavandula pubescens, Sonchus oleraceus, Verbesina encelioides) were collected from Tabuk area, Al-Wajh Province at Pedi \& Al-Khur villages. More data on these plants are given in Table 1. Fig. 1 shows photos of the collected plants taken by the first Author. The six plants grow wild in this mountainous region of north-western Saudi Arabia, mainly during the rainy season. Further identification of the plants was provided by Prof. Amal Fakhry (University of Tabuk, Saudia Arabia).

\subsection{Preparation of Crude Alcoholic Extracts}

The collected plant material was air-dried at room temperature, in the shade. The dried material was ground to fine powder and allowed to macerate in methanol for 18-24 h, at ambient temperature, with occasional agitation. The clear solvent layer was

Table 1 Names, letter codes and collection site/date of the six plants of the study.

\begin{tabular}{|c|c|c|c|c|}
\hline \multirow{2}{*}{ Scientific name } & \multirow{2}{*}{ Plant family } & \multirow{2}{*}{ Letter code } & \multicolumn{2}{|c|}{ Collection } \\
\hline & & & Site & Date \\
\hline Arnebia decumbens & Boraginaceae & A & Alkur village & $1 / 21 / 2014$ \\
\hline Caralluma sinaica & Apocynaceae (Asclepiadaceae) & $\mathrm{C}$ & Alkur village & $1 / 23 / 2014$ \\
\hline Fagonia tenuifolia & Zygophyllaceae & $\mathrm{W}$ & Alkur village & $1 / 23 / 2014$ \\
\hline Lavandula pubescens & Labiatae & $\mathrm{Z}$ & Alkur village & $1 / 23 / 2014$ \\
\hline Sonchus oleraceus & Asteraceae & $\mathrm{F}$ & Beda village & $3 / 18 / 2014$ \\
\hline Verbesina encelioides & Asteraceae & $\mathrm{S}$ & Alkur village & $3 / 18 / 2014$ \\
\hline
\end{tabular}




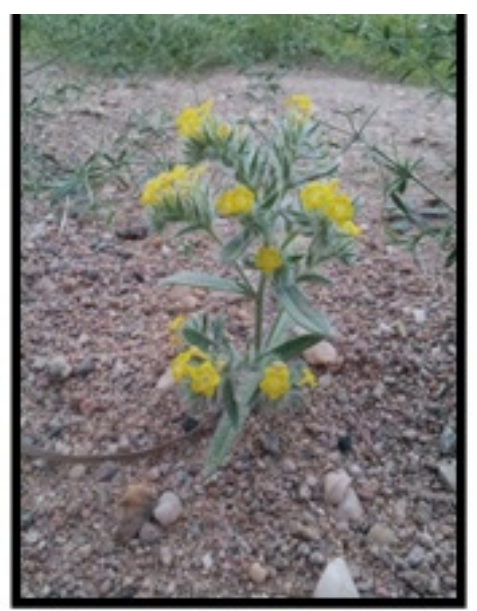

1

\section{4}

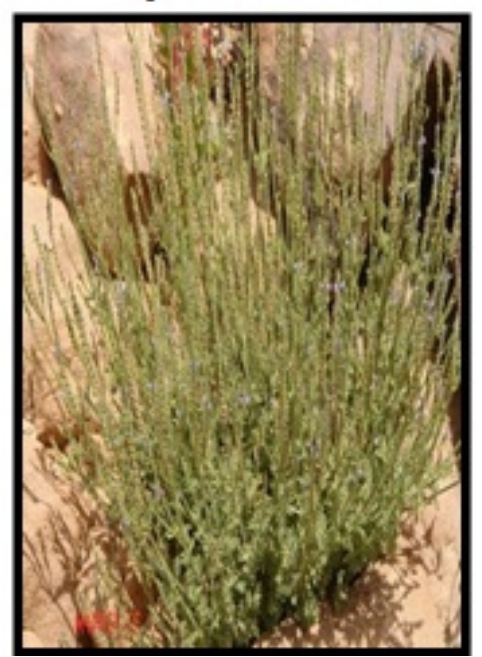

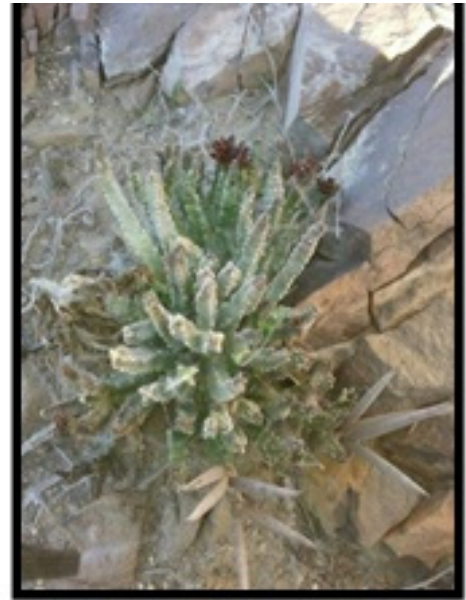

2

5

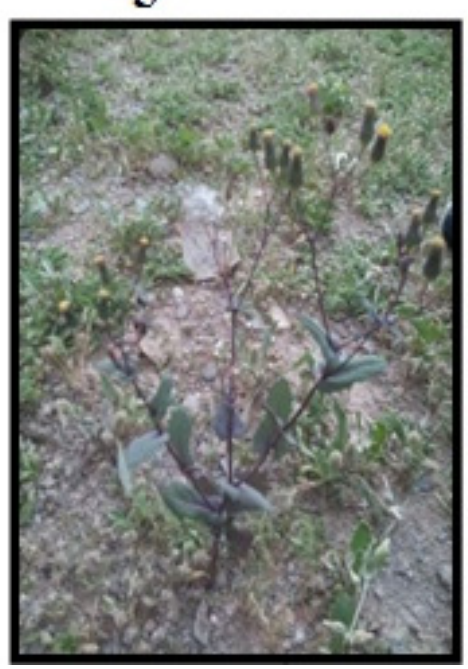

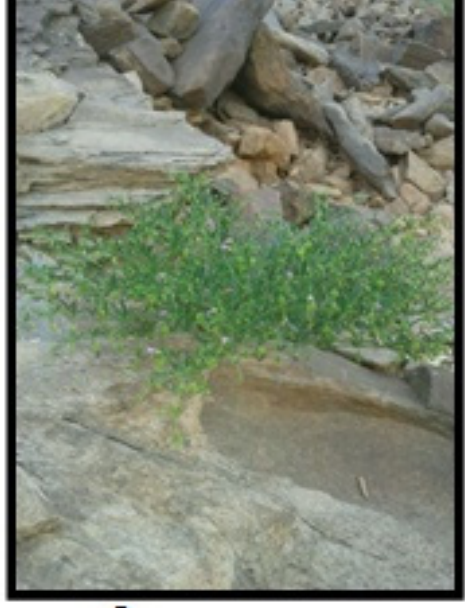

3

6

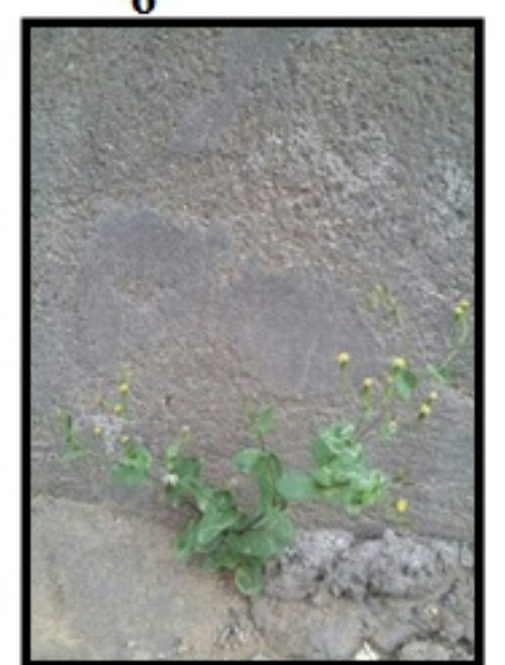

Fig. 1 Selected plants of the study. 1 = Arnebia decumbens, $2=$ Caralluma sinaica, $3=$ Fagonia tenuifolia, $4=$ Lavandula pubescens, 5 = Sonchus oleraceus, 6 = Verbesina encelioides.

decanted and the marc re-extracted with fresh methanol. The combined extracts were filtered and the solvent volume reduced under vacuum in a rotary evaporator. The concentrate was made to volume as required for subsequent tests.

\subsection{Antitumor Bioassay}

(a) Reagents: FBC (fetal bovine serum) and L-glutamine were obtained from GibcoInvirtrogen Co. (Scotland, UK). PRMI-1640 was from Cambrex (New Jersey, USA). DMSO (Dimethyl sulfoxide), doxorubicin, penicillin, streptomycin and SRB (sulforhodamine B) were from Sigma Chemical Co. (St. Louis, USA).

(b) Cell cultures: Three human tumor cell lines,
MCF-7 (breast adenocarcinoma), NCI-H460 (non-small lung cancer), and SF-268 (CNS cancer) were used. Cell line MCF-7 was obtained from ECACC (European Collection of Cell Cultures), Salisbury, UK. NCI-H460, SF-268 and normal fibroblast cells (WI 38) were kindly provided by the NCI (National Cancer Institute), Cairo, Egypt. They were grown as monolayers and routinely maintained in RPMI-1640 medium supplemented with 5\% heat inactivated FBS, $2 \mathrm{mM}$ glutamine and antibiotic (penicillin $100 \mathrm{U} / \mathrm{mL}$, streptomycin $100 \mu \mathrm{g}$ ), at $37{ }^{\circ} \mathrm{C}$ in a humidified atmosphere containing $55 \% \mathrm{CO}_{2}$. Exponentially growing cells were obtained by plating $1.5 \times 105$ cells $/ \mathrm{mL}$ for MCF-7 and SF-268 and $0.75 \times$ 
104 cells $/ \mathrm{mL}$ for NCI-H460, followed by $48 \mathrm{~h}$ of incubation. The effect of the vehicle solvent DMSO on the growth of these cell lines was evaluated in all experiments by exposing untreated control cells to the maximum concentration (5\%). Doxorubicin was used as a positive control and tested in the same manner.

The effects of plant extracts (and the control) on the in vitro growth of human tumor cells were evaluated according to the procedure adopted by the NCI (National Cancer Institute), USA that uses the protein-binding dye sulforhodamine $\mathrm{B}$ to assess cell growth [20,21]. Briefly, exponentially growing cells in 96-well plates were exposed for $48 \mathrm{~h}$ to five serial concentrations of each plant extract or control (doxorubicin), starting from a maximum concentration of $150 \mu \mathrm{M}$ for doxorubicin. For plant extracts the weight-equivalent for this molar concentration of doxorubicin $(81.0 \mu \mathrm{g} / \mathrm{mL})$ was taken. Following this exposure period adherent cells were fixed, washed, and stained. The bound stain was solubilized and the absorbance was measured at $492 \mathrm{~nm}$ in a plate reader (Bio-Tek Instrument Inc., Power wave XS, Wincoski, USA). For each test preparation and cell line, a dose-response curve was obtained and the growth inhibition of $50 \% \quad\left(\mathrm{G}_{\mathrm{I}} \quad 50\right)$, corresponding to concentration of the preparation that inhibit $50 \%$ of the net cell growth was calculated.

\subsection{Assay of DHFR Activity}

This enzyme activity was determined using a commercially available kit from Sigma Co., USA. DHFR catalyzes the biological reduction of DHF (dihyrofolate) to THF (tetrahydrofolate), with the cofactor NADP (nicotinamide adenine dinucleotide phosphate) acting as the hydrogen donor:

$\mathrm{DHF}+\mathrm{NADP}+\mathrm{H}^{+} \leftrightarrow \mathrm{THF}+\mathrm{NADP}^{+}$

The principle of the assay was to spectrophotometrically follow the decrease in absorbance at $340 \mathrm{~nm}$, due to decrease in NADP concentration consumed in the reaction. A Beckman DU spectrophotometer was used set to the kinetic program. Enzyme activities were calculated as per the Sigma kit bulletin.

\subsection{Phytochemical Screening}

Phytochemical screening of plant extracts was carried out semi-quantitatively for secondary plant products (Table 2). The chemical reagents recommended by Harborne, J. B. [22] and Wagner, H. [23] were used.

\section{Results and Discussion}

\subsection{Phytochemical Screening}

Table 2 shows results of semi-quantitative screening, of the six Saudi Arabian plants used in folk medicine, for secondary plant products by class or sub-class. The three major classes, namely, alkaloids (containing secondary, tertiary and quaternary nitrogen), terpenoids (sterols and cardiac glycosides), phenolic compounds (coumarins, leucoanthocyanidins, anthraquinones, flavonoids and tannins) as well as glycoside derivatives, were detected in the six plants. Most notable was the paucity of cardiac glycosides, a group of secondary plant products of restricted distribution within the plant kingdom.

\subsection{Antitumor Activity}

Table 3 and Fig. 2 show results of the antitumor assay of the plant extracts (and the standard antitumor compound doxorubicin) presented as $\mathrm{G}_{\mathrm{I}} 50$ values. $\mathrm{G}_{\mathrm{I}} 50$ is the concentration of the plant extract (or of doxorubicin) that caused $50 \%$ inhibition of cell growth after continuous incubation with each tumor cell line for $48 \mathrm{~h}$ and was calculated using a dose-response curve involving a range of concentrations for each test preparation and cell line. Doxorubicin, as expected, was inhibitory towards the growth of the three human tumor cell lines (low $\mathrm{G}_{\mathrm{I}} 50$ values). Among the six plant extracts tested, the most remarkable were those of Caralluma sinaica and Fagonia tenuifolia. Caralluma extract showed strong antitumor activity (low $\mathrm{G}_{\mathrm{I}} 50$ ) against the three human tumor cell lines. Fagonia 
Table 2 Phytochemical screening of the six selected plants.

\begin{tabular}{lllllll}
\hline Plant & Alkaloids & Steroids & Cardiac glycosides & Flavonoids & Tannins & Anthra-quinones \\
\hline Arnebia decumbens & + & + & + & +++ & + & + \\
Carallumasinica & ++ & + & + & ++ & + & + \\
Fagonia tenuifolia & + & + & - & ++ & + & + \\
Lavandula pubescens & + & +++ & - & + & + & - \\
Sonchus oleraceus & + & + & - & +++ & + & + \\
Verbesina encelioides & ++ & + & - & + & + & + \\
\hline
\end{tabular}

Table 3 Effect of plant extracts (and of doxorubicin standard) on the growth of three human tumor cell lines. The figures, in $\mu \mathrm{g} / \mathrm{L}$, represent the concentration of the plant extract (or of doxorubicin) that caused $50 \%$ inhibition of cell growth $\left(G_{\mathrm{I}} 50\right)$ after continuous incubation with each tumor cell line for $48 \mathrm{~h}$. The results are means $\pm \mathrm{SEM}$ of three independent experiments performed in duplicates.

\begin{tabular}{llll}
\hline & MCF-7 & NCI-H460 & SF-268 \\
\hline Arnebia decumbens & $38.22 \pm 4.18$ & $33.03 \pm 8.01$ & $22.59 \pm 4.01$ \\
Fagonia tenuifolia & $6.04 \pm 2.43$ & $26.72 \pm 2.86$ & $4.40 \pm 1.93$ \\
Sonchus oleraceus & $33.10 \pm 1.41$ & $20.68 \pm 4.33$ & $20.32 \pm 2.82$ \\
Lavandula pubescens & $33.66 \pm 8.35$ & $40.83 \pm 12.32$ & $30.41 \pm 2.28$ \\
Caralluma sinaica & $0.60 \pm 0.08$ & $0.02 \pm 0.002$ & $2.01 \pm 0.85$ \\
Verbesina encelioides & $26.32 \pm 2.42$ & $28.65 \pm 2.89$ & $26.82 \pm 8.54$ \\
Doxorubicin & $0.04 \pm 0.008$ & $0.09 \pm 0.008$ & $0.09 \pm 0.007$ \\
\hline
\end{tabular}

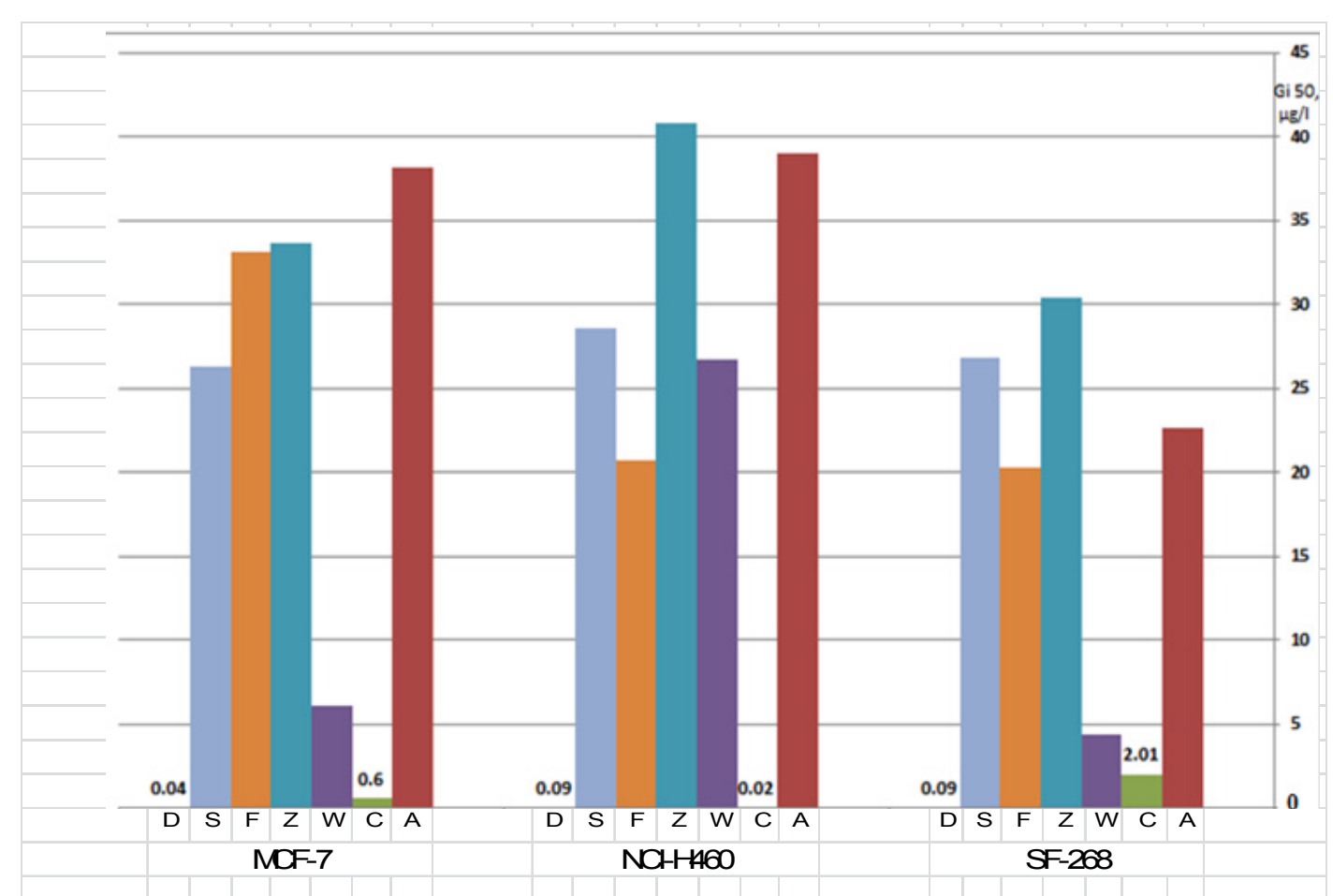

Fig. 2 Effect of crude plant extracts on growth of three human tumor cell lines. The bars represent values of $\mathbf{G}_{\mathrm{I}} \mathbf{5 0} \mathrm{in} \mu \mathrm{g} / \mathrm{L}$. Actual of values of $\mathrm{G}_{\mathbf{1}} \mathbf{5 0}$ too low to be apparent at this scale are typed above the bars. Each plant extract (or doxorubicin standard) was tested for growth inhibition using the three cell lines: MCF-7, NCI-H460 and SF-268. Plant extracts were: A = Arnebia decumbens, $\mathrm{C}=$ Caralluma sinaica, $\mathrm{W}=$ Fagonia tenuifolia, $\mathrm{Z}=$ Lavandula pubescens, $\mathrm{F}=$ Sonchus oleraceus, $\mathrm{S}=$ Verbesina encelioides and $D=$ doxorubicin standard. 
Table 4 DHFR inhibitory activity of plant extracts and of methotrexate standard.

\begin{tabular}{ll}
\hline Plant extract (or methotrexate) & $\mathrm{IC}_{50}(\mu \mathrm{g} / \mathrm{L})$ \\
\hline Arnebia decumbens & 21.0 \\
Fagonia tenuifolia & 18.0 \\
Sonchus oleraceus & 0.06 \\
Lavandula pubescens & 40.0 \\
Caralluma sinaica & 0.10 \\
Verbesina encelioide & 35.0 \\
\hline
\end{tabular}

extract, on the other hand, was quite inhibitory to the growth of CNS cancer and breast cancer cell lines but much less so against lung cancer cells. Less dramatic tumor cell growth inhibition was observed for extracts of Sonchus oleraceus (against lung and CNS cancer) and for Arnebia decumbens (against CNS cancer cell line). All other plant extracts tested were inactive in the antitumor assay performed (Table 3). A direct comparison of the antitumor activities of doxorubicin and the active plant extracts is not possible at this stage of the research; as such molar comparisons would require knowledge of the molecular weight of the active plant ingredient.

Thus Caralluma and Fagonia plants are potential anticancer-drug sources worthy of further investigations.

\subsection{Antifolate Activity}

Table 4 shows results of in vitro inhibition of the enzyme dihydrofolatereductase (antifolate) activity of alcoholic extracts of the six plants of the study as compared to the known enzyme inhibitor methotrexate. Methotrexate reduced the activity of DHFR by $50 \%$ $\left(\mathrm{IC}_{50}\right.$ value) at the low concentration of $0.08 \mu \mathrm{g}$ per litre (Table 4). While extracts of species of Lavandula and of Verbisina had no inhibitory effect on the enzyme, extracts of Sonchus oleraceus and Caralluma sinaica were strongly inhibitory to DHFR. Extracts of species of Fagonia (very active in the antitumor assay) and of Arnebia may have slight inhibitory effects on the activity of DHFR.

As mentioned in the Introduction, inhibitors of DHFR are potential drugs for the treatment of cancer malaria, leishmania and trypanosomiasis as well as bacterial infections. Thus, the authors' study provides scientific support for the use of Caralluma sinaica as a folk medicinal anticancer plant. Moreover, the fact that extracts of Caralluma sinaica were active both in the antitumor assay (Table 3) and the antifolate assay (Table 4) suggests that the mechanism of anticancer activity of this plant is through DHFR inhibition. By the same token, the mechanism of action of antitumor activity found for the extract of Fagonia tenuifolia (Table 3) may follow a different pathway, given its low inhibition of DHFR (Table 4).

On the other hand, extracts of Sonchus oleraceus had none or little antitumor activity but were very active as DHFR inhibitors. This suggests a potential for the plant as a source of drugs for use as antimalarials, anti-leishmanials, etc. It also gives scientific support for the folk-medicinal use of the plant as an antimalarial [14]. The fact that extracts of this plant were potent DHFR inhibitors may explain the mechanism of action of the antipyretic effects of this plant reported in rats [14].

\section{Acknowlegments}

The authors would like to acknowledge financial support for this work, from the DSR (Deanship of Scientific Research) University of Tabuk, Tabuk, Saudi Arabia, (under grant No. S-1435-0181). Thanks are extended to Prof. Salah A. A. Elhussein for reading and commenting on the manuscript.

\section{References}

[1] Cragg, G. M., and Newman, D. J. 2013. "Natural Products: A Continuing Source of Novel Drug Leads." Biochimicaet Biophysica Acta 1830 (6): 3670-95.

[2] Ron, Q., Xing, H., Su, Z. B., Yang, Q., and Yang, Z. 2013. "Recent Advances in Separation of Bioactive Natural Products." Chinese Journal of Chemical Engineering 21 (9): 937-52.

[3] Shahid-uI-Islam, Shahid, M., and Mohammed, F. 2013. "Perspectives for Natural Product Based Agents Derived from Industrial Plants in Textile Applications-A Review." Journal of Cleaner Production 57: 2-18. 
[4] Abali, E. E., Skacel, N. E., Celikkaya, H., and Hsieh, Y. 2008. "Chapter 9. Regulation of Human Dhydrofolate Reductase Activity and Expression.” In Vitamins and Hormones, Amesterdam: Elsevier.

[5] Gonen, N., and Assaraf, Y. G. 2012. "Antifolates in Cancer Therapy: Structure, Activity and Mechanisms of Drug Resistance." Drug Resistance Update 15 (4): 183-201.

[6] Anderson, C. 2005. "Targeting DHFR in Parasitic Protozoa." Drug Discovery Today 10 (2): 121-8.

[7] Gilbert, H. 2002. "Inhibitors of Dihydrofolatereductase in Leishmania and Trypanosomes." Biochimicaet Biophysica Acta-Molecular Basis of Disease 1587 (2-3): 249-56.

[8] Hawser, S., Locuro, S., and Islam, K. 2006. "Dihydrofolate Reductase Inhibitors as Antibacterial Agents.” Biochemical Pharmacology 71 (7): 941-8.

[9] Jain, S. C., Singh, B., and Jain, R. 2000. "Arnebins and Antimicrobial Activities of Arnebia hispidissima DC. Cell Cultures." Phytomedicine 6 (6): 474-6.

[10] Shukla, Y. J., Khan, I. A., Geoffroy, P., and Miesch, M. 2013. "Chapter 9-14ß-Hydroxypregnanes from Succulent Plants Belonging to Hoodia gordonii and Caralluma Genus: Extraction, Biological Activities and Synthesis." In Studies in Natural Products Chemistry, edited by Atta-ur-Rahman. Amesterdam: Elsevier.

[11] Adnan, M., Jan, S., Mussarat, S., Tariq, A., Begum, S., Afroz, A., and Shinwari, Z. K. 2014. "A Review on Ethnobotany, Phytochemistry and Pharmacology of Plant Genus Caralluma R. Br.” J. Pharm. Pharmacol 66 (10): 1351-68.

[12] Ansari, A. A., Abbas, Z. K., Saggu, S., Rehman, H., and Moawed, M. M. 2014. "Growth Responses of Lavandula pubescens to Temperature Regimes of Tabuk, Saudi Arabia." Journal of Medicinal Plants Studies 2 (6): $38-41$.

[13] Alkal, A. G., Ali, N. A. A., Wurster, M., Fadil, C., and Sharaf, I. 2011. "Lavandula pubescens-A Potential Source of Carvacol-Rich Essential Oil in Yemen." University of Aden Journal of Natural and Applied Science 1: 1-13.
[14] Viela, F. C., Bitencourt, A. D., Cabral, L. D. M., Franqui, L. S., Soncini, R., and Giusti-Paiva, A. 2010. "Anti-inflammatory and Antipyretic Effects of Sonchus oleraceus in Rats." Journal of Ethnopharmacology 127 (3): 737-41.

[15] Sharma, P., Mohan, L., and Srivastava, C. N. 2006. "Phytoextract-Induced Developmental Deformities in Malaria Vector." Bioresource Technology 97 (14): 1599-604.

[16] Yin, J., Kwon, G., and Wang, M. 2007. "The Antioxidant and Cytotoxic Activities of Sonchus oleraceus L. extracts." Nutrition Research and Practice 1 (3): 189-94.

[17] Viela, F. C., Soncini, R., and Giusti-Paiva, A. 2009. “Anxiolytic-Like Effects of Sonchus oleraceus L. in Mice." Journal of Ethnopharmacology 124 (2): 325-7.

[18] Sindhu, R., and Arora, S. "Hypoglycemic Potential of Verbesina encelioidesBenth. Roots." West African Journal of Pharmacology and Drug Research 25.

[19] Lopez, T. A., Campero, C. M., Chayer, R., Cosentino, B., and Carasino, M. 1996. "Experimental Toxicity of Verbesina encelloides in Sheep and Isolation of Galegine." Vet. Hum. Toxicol. 38 (6): 417-9.

[20] Skehan, P., Storeng, R., Scudiro, D., Monks, A., McMahon, J., Vistica, D., Warren, J. T., Bokesch, H., Kenny, S., and Boyd, M. R. 1990. "New Coloimetric Cytotoxicity Assay for Anticancer-Drug Screening." $J$. Natl. Cancer Inst. 82 (13): 1107-12.

[21] Clinical and Laboratory Standards Institute. Performance Standards for Antimicrobial Susceptibility Testing; Seventeenth Informational Supplement. CLSI document M100-S17 [ISBN 1-56238-625-5]. CLSI, Wayne, PA, 2007. Accessed May 10, 2015. http:/microbiolab-bg.com/wp-content/uploads/2015/05/cl si. pdf.

[22] Harborne, J. B. 1998. Phytochemical Methods: A Guide to Modern Techniques of Plant Analysis. London: Chapman and Hall.

[23] Wagner, H., and Bladt, S. 1996. Plant Drug Analysis: A Thin Layer Chromatography Atlas. Berlin: Springer-Verlag. 